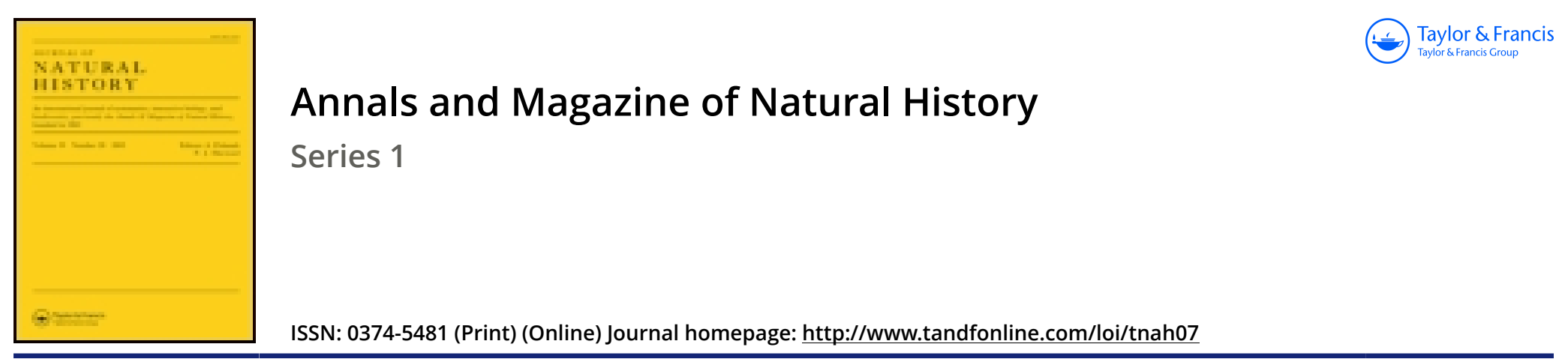

\title{
XXVI.-The Birds of Ireland
}

\section{Wm. Thompson Esq.}

To cite this article: Wm. Thompson Esq. (1842) XXVI.-The Birds of Ireland, Annals and Magazine of Natural History, 10:64, 171-179, DOI: 10.1080/03745484209445217

To link to this article: http://dx.doi.org/10.1080/03745484209445217

曲 Published online: 04 Dec 2009.

Submit your article to this journal 중

Q View related articles $₫$ 
fig. 2.) the tube has been strctched, the fibre breaks up into rings; and at that part nearest the testa where the pressure is considerable, the fibres at first are simply approximated; nearcr still to the testa we have union of the fibres, and the reticulated duct produced.

August 9, 1812.

\section{DESCRIPTION OF THE PLATE. PLATEV.}

Fig. 1. Transrerse section of a bundle of dotted tules from Pteris; $a$, the circular or elliptical orifices.

Fig. 2. Dotted tube from the sane; $a$, conical termination.

Fig. 3. The same; $a$, overlapping extremities.

Fig. 4. The sane, showing how the extended tube uncoils without breaking; $l$, the black line spoken of above.

Fig. 5. and 9. Show how the thicker portion when torn presents a ragged edge : this preparation was dried, and the thinner membrane deficient.

Fig. G. Early dotted tubes from Aspidium Filix mas.

Fig. 7. Transperse section of bundle of tubes from Pleris : when the internal surface of the tube is brought into focus the transverse bars may be secn.

Fig. 8. and 9. Fibres withdrawn from the membrane in Aspidium Filix mas.

XXVI.-The Birds of Ireland. By WM. Thompson, Esq., Vice-Pres. Nat. Hist. Socicty of Belfast.

[Continued from p. 59.]

No. 13. Hirundinide (continued).

Commox Swrt, Cypselus murarius, Temm. Although this bird is common in favourite localities, the species must be set down with reference to Ireland generally as but partially distributed. Along the western range of the island it is rather scarce, and in some cxtensive districts is never to be met with.

The swift is more regular as to the time of its appearance around Belfast than any of the genus Hirundo. It may generally be seen during the first week of May, and frequently on the 2nd day of that month.

In his 'Illustrations of British Ornithology;' Mr. Selby observes, "It has been remarked that these birds delight in sultry weather, with approaching thunder-storms, at such times flying in small partics, with peculiar violence; and as they pass near steeples, towers, or corners of buildings, uttering loud screams, which White, in his ' Natural History of Selborne,' supposes to be a sort of serenade to their respective families. This is fanciful and pretty; but I should rather be inclined to reason the opposite way, and to consider this action and $\mathrm{cry}$ as the consequences of irritability, excited by the 
highly electrical state of the atmosphere at such times." With Mr. Selby I agree in considering the remark of White respecting the scream of the swift to be merely "fanciful and pretty," as I have heard these birds scream in the manner described so soon after their arrival as to afford sufficient proof that the cry did not proceed from the " males serenading their sitting hens," as at the time incubation had not commenced*. But I cannot coincide in opinion with Mr. Selby that " this action and cry are the consequences of irritability. excited by the highly electrical state of the atmosphere at such times." This idea differing from my own previous to the perusal of the admirable work in which it appeared, I, for two summers, gave some attention to the subject, to see how far my preconceived opinion was justified. In the years 1832 and 1833, from the 7 th and 9 th of May, the days on which the swifts first came under my observation about Belfast, until the 1st and 3rd of June (when I left home), they daily, in dull and gloomy as well as bright and cloudless weather, kept flying about in small parties, screaming loudly.

The following particular notices on this subject are abbreviated from my Journal :-

MIay 24th, 1832.-For the last eight or ten days the swift's scream has been daily heard; and when present this evening at the closing sessional meeting of the Historic Debating Society, the swifts obtruded themselves on my attention by flying, " in small parties," closely past the windows, screaming most furiously. "Though amusing to the ornithologist, it must have been very annoying to the assembled company to be "serenaded" by their ill-timed scream, which not only jarred most discordantly with the "eloquent music" dis. coursed within, but for the time being entirely drowned the voices of the speakers, and indeed almost seemed to be intended as a mockery of what was passing there. During these ten days the weather has been rather dark and cloudy; the barometer remarkably stationary, and very high. With the exception of a few showers on one day, no rain has fallen.

May 27th and June 3rd, 1832.-Weather remarkably fine and warm; sky almost cloudless. The screaming of swifts heard above every other sound, about the localities frequented by them.

Nay 22nd, 1833.-After eight this evening, which was very warm and the sky cloudless, swifts were flying about in little parties of three and four, and noisy as usual : two of these parties would occasionally join, and continue together for a short time screaming vo. ciferously. These evolutions have always seemed to me manifestations of pure enjoyment, and I have considered the swift's peculiar cry generally indicative of pleasure. When these parties were about to meet, and when just separating, their power of screaming was ex-

* I have often remarked what doubtless led White to conjecture that the cry of the swift is the serenade of the males to "their sitting lens," as, at the season of incubation, these birds (but of which sex I cannot say) may often be observed flying abuut in the neighbourloud of their nests, and screaming only "when they come close to the walls or cares." 
erted to the utmost*. Similar evolutions, in which a much greater number of these birds participatcd, were witnesed on the 24th inst. ; the weather being similar to what it was on the $22 \mathrm{nd}$, in regrard to fineness and a cloudless sky. The barometer was very high and stationary on both evenings. The state of the barometer and weather has been mentioned, that some idea nay be formed whether or not the atmosphere could have been " highly electrical" throughout the varicd weather described, or indecd daily throughout that of any two months in this climatet.

Swifts prefer to nestle in lofty edifices, especially when in a state of dilapidation + ; but in the north of Ireland, where these do not often occur, they content themselves with more humble dwellings. I have remarked that in many of our northern towns $\$$, where swifts are as plentiful as in any country, that they select for their domicile the eaves of the oldest houses, or those from which the fast encruaching spirit of improvement has not yet banished the thatched roofs. On the 8th of July 1833, I observed many of these birds flying under the eaves and clinging to the walls of occupicd two-story houses of this kind in the town of Antrim, and although they and the martins appeared an indiscriminate multitude when flying about the street, their places of nidification were quite distinct, the martins building on the south, and the swifts confining themselves to the north side : on a house just opposite the chief abode of the latter, I reckoned about twenty nests of the martin. When in the town of Ballymoney, on the same day, sereral swifts were observed to fly under the thatch of a house similar to that described, whilst against it appeared some inhabited nests of the martin. On the 24th of June 1834, the swift was remarked to have similar nestling-places in Lisburn and Banbridge. In all the above-mentioned localities these birds were flying about in groups and screaming violently, the weather being delightfully warm, and the sky not only " purely heautifully blue," but not a cloud visible. For a week after the former date the weather continued very warm and dry.

In Belfast, where houses such as those described are not to be met with, I lave known the swift's nest to be placed under the window-

- Mr. Macgillivray remarks, "that the loudest and most frequent cries are hearl when birds are evidently in active and successful pursuit." At the times abose alluded to they certainly were not feeding.

+ Mr. Macgillirray, in his 'Britibh Birds,' rol. iii. pp. 619 and 622, enters fully into the subject of the swift's screaming. His obserrations of 1837 very generally agree with mine, made a few years before. Dr. J. I). Marshall, in his memoir on the Statistics and Natural History of the island of Rathlin, where swifts are plentiful, states, that the result of his observations is opprosed to the views of White and Selby: He believes the loud screaming of these birds to be particularly induced by fine weather and an abundance of food.

‡ When on Ram's Island, in Lough Neagh, in the month of June 1833, I remarked sercral of these birds fying in the vicinity of the ancient round tower, whose "rents of ruin" were most probably their tenyorary abiding place.

$\$$ Swifts especially delight in large open spaces in towns. 
sills of houses newly erected, to which the bird gained access by means of an aperture, about an inch in width, that the careless builder had neglected to close up. An ornithological friend has seen swifts fly under the eaves of the low thatched cottages in the rillage of .Mlagheralin (county Down), where they doubtless nestle.

This sjecies, like the martin, frequents the basaltic precipices of the north coast of Ireland, from their southern extremity at the Cave hill near Belfast, to their northern termination above the sand-hills of Magilligan; and, from their being ever present in these situations during their sojourn with us, they doubtless have their dwellings in their crevices*.

In the fifth volume of the 'Mlag. of Nat. Hist.,' p. 736, Mr. Couch remarks, "It is not long that swifts hawe frequented stations conrenient for my observation. At first they were about two pairs, but they have now increased to four or five; and it is singular, that according to my observation, there is always an odd bird." A similar circumstance was, for the first time, remarked by me in the summer of 1829 , when three swifts repaired to Wolfhillt, and took up their abode between the slates and window-frame of a loft not more than twenty feet in height. Here, where a shot was not permitted to be fired, and the odd bird could not have lost its partner by the fouling-

* White of Selborne mentions sujfts " brecding in the sides of a deep chalk-pit at Odiham." At the end of June 1835; I observed numbers of these birds alout the high limestone cliffs which rise in picturesque beauty above the river Derwent, at Matlock in Derbyshire, where it was presumed that they nestled.

+ This locality: situated about three miles from Belfast, is elevated 500 fect above the sca, and is a farourite lannt of the IIrundinida. During the sojourn of the swift, this species, with the three others, may frequently be seen at one view, the swallow, martin and sand martin swerping in company over the ponde, whilst the swift, though generally maintaining a superior altitude, occasionally breaks through their ranks; the whole of the species, on such occasions, and indect at all times, exhibiting the most perfect anity. The swift builds here under the eaves of an out-house, the rafters of which display the nest of the sirallow beneath them; under an adjoining roof the "cradlu" of the martin appears, and not more than a furlong distant is the burrow of the samb martin. It is extremely interesting to the lover of nature thus to beliold at a glance all the species of these attractive summer wanderers that regularly visit the British Islands; and where they do thus appear, there are generally some charming features of natural scenery:

When at Kilrea in July 1839, where the banks of the river Bann are picturesquely rooded, and the expansive stream of water is impeded in its progress from Lough Neagh to the ocean by low and scattered rocks which rise here and there above it, and in a moment change the smootl mirror of its surface into a scene of active and "lusty life," such as delighteth the angler's heart, I observed the four species, and swifts, not less than a hundred in number, keeping almost on the same level with the others.

In Malta, again, on the 17 th of April 1841 , the day very fine and warn, our four Hirundinille were in like manner observed flying low and in company wherever we walked abont the island, and all the species in numbers similar to what they are in their most faroured lraunts in the British Islands. This is a fortniglit earlier than the swift generally appears in the north of Ircland. 
piece, the circumstance was considered as " passing strange." During three months, the usual period of the swift's presence in this country, the three mature individuals only appeared. 'The following year also an odd number of these birds was observed at Wolfhill, there being either five or seven. It may be stated, that during these two summers the houses there had, in regard to fallen plaster and the growth of lichens, mosses, \&c., rather more of a picturesque appearance than is consistent with the most perfect order, and that in the autumn of 1830 they wcre all repaired and roughcast, the swifts' eyrie being most carefully protected from the hands of the renovator; but, notwithstanding this, the species has never since tenanted the place.

Swifts generally keep at such an altitude, that the vicinity of water is not enlivened by their presence as it is by that of some of the Hirundines, yet they may occasionally be seen flying over Belfast Bay (particularly about the time of high-water), as well as skimming the surface of ponds and rivers. Once only have I witnessed these birds keeping regularly at a lower eleration than swallows. 'This was on the 3rd of July 1838, a beautiful sun-bright day, when numbers of them ajpleared fying over Strangford Lough, near Portaferry, at from twenty to forty yards above the surface of the sea, while, in the stratum of air immediately above, swallows were abundent.

Bewick remarls that swifts (vol. i. p. 267, ed. of 1821) " are said to aroid heat, and for this reason pass the middle of the day in their holes, [and that] in the morning and the evening they go out in quest of provision." Mr. Macgillivray too observes, that "in dry and sunny weather [the swift] generally rests in the middle of the day." This has, I conceive, been assumed from the circumstance that swifts are not seen about their breeding launts throughout the day, like the swallow and martin. Instead, however, of lying concealed at such times, they are ranging far abroad. During our very warmest and brightest days I have commonly seen them sweeping in great numbers over the mountain heaths and around the summit of Divis*, the highest mountain in our neighbourhoodt, and near to which they have not any nestling-places. Towards evening they return from these comparatively distant flights, and are then seen about their accustomed haunts for some time previous to rctiring for the night, having thus led persons to believe that the evening is one of their favourite times for stirring out. Swifts may likewise be occasionally seen on wing about their nests throughout the very warmest days 4 .

* 1575 fect above the sea.

+ When here on the 15 th of May 1836 (a remarkably fine day), to witness the eclipse of the sun, I saw fully as many swifts as had ever appeared when the season was fatther adranced.

In like manner I remarked them on the 6th and 7th of May 1841, about the lofty mountain tops, and there only, in the island of Syra, one of the group of the Cyclades. Captain Cook, in lis 'Sketches in Spain,' mentions a similar propensity of the alpine swift, in the following words: "I have heard they were not uncommon in Catalonia, but I never met with them, probably from their habit of going to feed at vast heights and distances in the daytime, which prevents their being scen." (Vol. ii. p. 276.)

t An intelligent shooter and taxidermist states that two swifts' nests which 
In the 'Natural History of Selborne' (Letter 21), White remarks of the swift, that " in the longest days it does not withdraw to rest till a quarter before nine in the evening, being the latest of all day birds." In Belfast it may be seen about midsummer at nine; and not.rarely for some time after that hour, before which the three species of Hirundo have generally retired.

The swift generally leaves Belfast about the 12th of August, but in $1 S 401$ saw a number of them here on the 19 th of that month, and in 1832 on the 20 th ; in 1833 I remarked about twenty in company, in its vicinity, so late as the 30th. These were pursuing their prey most leisurely, at about thirty yards from the ground, many swallows and martins occupying the space immediately beneath them : and each, the Cypselus and Hirundo, occasionally breaking through the others' ranks. The month of August was much colder than usual this year, but that circumstance could hardly have influenced the swift in remaining beyond its ordinary time of departure, as the first assemblage of swallows and martins, constituting a vist multitude, was congregated for migration at the same time and place, and on the same day they all departed. On the 4th of September 1835, swifts were observed by a acientific friend about Dunluce Castle, near the Giants' Causeway; and on the 11th of that month in the following year, three of these birds were seen by myself at Hillsborough (county Down), and many more of the Hirundinida, which appeared at some distance, were believed to be of this species. About the same place, many of the Hir. rustica were congregated preparatory to their departure. I have never witnessed any assembling together of swifts, towards the time of their migration, like that of the swallow and martin. During the period of their stay, they are, in farourite localities, generally to be seen in some quantity.

In the course of a tour made to the south and south-east of Europe, \&c., in 1841 , the swift was first met with at $M$ Ialta on the 17 th of April, when many appeared in company with the three conmon species of Hirundo-H. rustica, $H$. urbica, and $H$. riparia. None were secn during the passage of H.M.S. Beacon from Malta to the Morea, when numbers of $H$. rustica and $H$. urbica alighted on the vessel. On the 6th and 7th of May swifts were next met with, about the mountain tops in the island of Syra, when the weather was very fine and warm. 'lowards the end of the month they were seen at Sinyrna, and were abundant at Constantinople. Early in June they were numerous about a rocky islet north-cast of Port Nousa, in the island of Paros, and were breeding in the fissures of low marine cliffs. At the end of this month they were plentiful in Trieste; and in July at Venice (remarkably so here), Verona, Milan, \&c. At

he manually examined in the summer of 1839 vere placed on the wall-top of a two-story thatched houze, and were like a sparrow's nest in a similar situntion, but contained feker feathers - in the one nest were two eggs which had been long incubated, and were therefore the complement, or full number, and in the other were three young birds. Swifts have for some years built at this house, inside of which the common swallow as regularly nestles. 
Constantinople only were both the Cypsclus murarius and C. melba seen.

White of Selborne, and Mr. Macgillivray (Brit. Birds), give very copious and highly interesting accounts of the swift, from personal , servatiờ:

Alrixe Swift, Cypselus alpinus, Temm.-By the 'Dublin Penny Journal ' of March 1833, my attention was called to a rara avis said to have been killed at Rathfarnham, and preserved in the fine collection of native birds belonging to Thomas IV. Warren, Fsq. of Dublin.

On calling to see this bird, I found it to be the Cypselus alpintus. a species unrecorded as occurring in any part of Ireland; the specimen recognised as the alpine swift by $\mathrm{Mr}$. W' $\mathrm{m}$. Sinclaire, and communicated by him to Mr. Selby as an addition to the British fauna, having been obtained off Cape Clear, at the distance of some miles from land. Mr. Warren's specimen is incorrectly stated in the 'Joumal' to have been captured in the month of February, as, according to a note made by that gentleman when the circumstance occurred, the bird was sent to him from Rathfarnham, in the neighbourhood of Dublin, on the 14th of March, being then in a perfectly fresh state.

Four individuals of this species have since been met with in England, as particularly noticed in the 'British Birds' of Yarrell and Macrillivray.

The first place I met with the alpine swift was about ten miles to the north of Naples, on the 12th of August 1826, when a great number of them were obscrved associated together in flight, at a considerable altitude. The evolutions of this species in the air are similar to those of the common swift; but independently of their superior size, which at once distinguishes them from that bird, the white colour of a portion of the under plumare, from which they have received the name of 'white-bellied swift,' is very conspicuous, eren when the bird is at a considerable clevation.

When on the Continent in 1841 , this species was first seen by us on the 9th of April, when descending the Rhone from Lyons to Avignon. About half-way between these cities several appeared flying over the river, and a few were seen at all suitable places thence to Avignon. On the morning of the 28th of April, when entering the fine bay of Navarino, great numbers appeared carecring ligh overhead, and in walking through the petty town of the same name later in the day, alpine swifts were flying very low over the streets and houses, although the weather was delightfully warm and fine. On my visiting the island of Sphacteria, the western boundary of the bay, on the 29 th, these birds were very abundant. 'The attraction here was a range of noble precipitous cliffs which rise direct from the sea, at the western side of the island, and which were inhabited by them; just such a locality as would be tenanted by the common swift in the north of Ireland, where the basaltic precipices are resorted to. The day was as fine and warm as our northern summers ever boast, yet on walking along the top of the cliff, these Ann.\& Mrg. N. Hist. Tol. x. 
birds swept about low and in numbers, occasionally within a few fards of my hend. In general appearance and flight they are very similar to the common swift : they are very noisy, almost constantly uttering a loud twitter; besides which they occasionally give a brief scream, nowise resembling the long-drawn and shrill cry of the common species. Towards the end of May I saw a fer alpine swifts at Constantinople, wheeling about the heights of Pera, and near the high tower of Galata, in which they probably nestle. In the month of June I met with this specics at the island of Paros, and about the Acropolis at $A$ thens. Throughout this tour the common swift was more frequently seen than the C. alpinus, and at one locality only did they both appear-this was at Constantinople, where the former species was abundant, and a few of the latter were observed. 'This seemed rather remarkable, as in no scene did I meet with the one species in which the other would not have appeared equally at home. The only difference in their habits which struck me was, that the alpine swift is more partial to cliffs than buildings, the common swift more partial to artificial structures than to rocks.

The Goatsucker, Caprimulgus Europeus, Linn., is a regular summer visitant to favourite localities in all quarters of the island, and of rare but occasional appearance elsewhere.

In the neighbourliood of Belfast it very rarely appears. A venerable sporting friend, who has been shooting here regularly in the season for abore sixty years, has not during that time met with a dozen of these birds, although there are sereral districts apparently well suited to them. In the wooded glen at the "Falls" one was seen by Mr. Wm. Sinclaire and myself gome years ago. It was perching lengthwise (as the species is well known to do), instead of across the branch of a fine beech tree, then displaying the tender and beautiful green of its young leaves. I am aware of four only having been killed, within twelve miles of Belfast, in the last fifteen years. Of these, the first was shot at Belvoir Park on the 28th of July 1827 ; the second, in the summer of 1835 , in the district of Malone; the third, on the 2.5th of Scptember in the same year, in Hillsborough Park; the fourth, on the lst of June 1840, at Bangor Castle: the stomach of this last was filled with the remains of seve. ral individuals of Geotrupes stercorarius. In the Ards, county Down, the goatsucker has not unfrequently been obeerved, by Georgc Mathews, Esq., at Springvale; and he informs me, that about Echlinville a few have been shot. It is a regular summer visitant to the Mourne mountains, more particularly in the vicinity of 'Tollymore Park*. The gamekeeper there informed me, in 1836, that lie had frequently found the nest of the goatsucker, and had ncver observed in any of them more than one egg. On the 2Sth of June 1838, he pointed out to me one of their nests : it was at the base of a young

* In Templeton's ' Catalogue of Vertebrate Animals' (Mag. Nat. Hist. vol. i. new series), this bird is noticed as " rare about Belfast; but [not] uncommon at Jlourne, county Down." The not before uucon:mon was omitted in the printing of the paper. 
tree planted in the spring, and which formed one of a young plantation on the mountain side. The bird was conscquently seen on the nest from some distance. She did not leare it until we approached within seven or cight paces, and then flew but a short distance before alighting:- - there were two very young birds on the bare ground; and about the distance of a foot from where they then were, it was stated that the egrs had been incubated.

'The roatsucker is noticed by J. V. Stewart, Esq., as common in the north of Doncgal. It is stated to be a regular vernal migrant to the county of Wicklow, - the "Vale of Oroca," a name familiar to the lovers of the "Irish Melodics," is said to be one of its favourite places of resort. Mr. R. Davis, jun., of Clonmel, says that this species is not uncommon, and annually breeds in some heath-clad moun. tains near that town. Captain Walker of Belmont, near Wexford, informs me that the "fern-owl" is rather common there. Mr. G. J. Allman, of Bandon, states that it is occasionally shot in that neighbourhood, but is not known to him as regularly frequenting any locality. A young plantation of limited extent, on the high banks above the river Blackwater, near Youghal, was pointed out to me in July $183 t$ by MIr. R. Ball as annually resorted to by these birds. In three specimens sent him from the locality, the ghostmoth (HIepialus Humuli) only was found; one stomach contained the remains of nine of these insects. When visiting the lakes of Killarney, in company with Mr. R. Ball, in July 1834, we had the gratification of seeing three goatsuckers hawking about, and very near to each other, as we were passing from the upper to the lower lake, and near the highly picturesque mountain called the Eagle's Nest : in the twilight, the white markings on the tail of one of them-said to denote the inale bird-were quite conspicuous. On the following evening we saw another between Innisfallen and Ross Island.

Dr. J. I. Drummond informs me, that when H.M.S. San Juan (of which he was surgeon) was anchored near Gibraltar, a few goatsuckers flew on board, in the spring of the year. During the passage of H.M.S. Beacon, at the end of April 1841, as particularly noticed in 'Annals,' vol. viii. p. 128, screral goatsuckers were scen, and some shot. On the evening of the Ist of June two were killed, and others seen, in the barren and now uninhabited island of Delos, by some of my companions, the officers of H.M.S. Magpie.

White, in lis 'History of Selborne,' gives an extremely interesting account of the goatsucker; Sir Wm. Jardine very fully notes its various modes of flight; and in Macgillivray's 'British Birds' an ample description is given by the author, to which are added valuable contributions from MIr. Harley and Mr. Weir; the observations of the former having been made near Lcicester, and the latter at Bathgate, Linlithgowshire.

[To be continued.] 